\title{
A STUDY OF THE MORPHOLOGY OF THE LEYDIG CELLS OF THE RAT AFTER UNILATERAL VASECTOMY
}

\author{
PABLO HERNÁNDEZ-JÁUREGUI AND JORGE OLIVERA
}

Departamento de Investigación Científica, del Centro Médico Nacional del Instituto Mexicano del Seguro Social, México City, Mexico*

(Received 18th March 1975)

Vasectomy is widely used as a method for sterilization, and recent surgical techniques have shown that the procedure can be reversed (Mehta \& Ramani, 1970; Pardanani et al., 1973, 1974). It is therefore mandatory to evaluate the function of the gonads following vasectomy. Flickinger (1972) described the effects on the testis of the rat up to 9 months after vasectomy and found no morphological changes in the seminiferous tubules; only brief mention was made of the morphology of the Leydig cells. The present work was therefore designed to examine possible modifications in the number and/or morphology of these cells in the rat after vasectomy.

Forty-five adult Wistar male rats weighing 200 to $250 \mathrm{~g}$ were used. All animals were subjected to $12 \mathrm{hr}$ light/12 hr dark and given Purina chow and water freely. The rats were allotted to three groups of fifteen each. Rats in Group I were vasectomized on the left side by section and double ligation (silk) of the ductus deferens through an abdominal incision. The rats in Group II were subjected to a sham operation on the left side, and those in Group III served as intact controls. Five animals from each Group were killed by cervical dislocation 2, 4 and 6 months after the surgical procedures.

Both testes of each animal were prepared for examination by light and electron microscopy. All testes were weighed, and immersed in Karnovsky's fixative (Karnovsky, 1965) for $1 \mathrm{hr}$ at room temperature. When the testes became hard, they were cut into $1-\mathrm{mm}$ slices and immersed in fresh Karnovsky's fixative for $2 \mathrm{hr}$ at $4^{\circ} \mathrm{C}$. After washing overnight in $0.1 \mathrm{~m}$-sodium cacodylate buffer, $\mathrm{pH}$ $7 \cdot 4$, the samples were post-fixed in $1 \%$ cacodylate-buffered $\mathrm{OsO}_{4}$ (Millonig, 1962) for $1 \mathrm{hr}$ at $4^{\circ} \mathrm{C}$. The tissue fragments were washed in the same cacodylate buffer, dehydrated in graded ethanols and embedded in araldite (Glauert \& Glauert, 1958) for $11 \frac{1}{2} \mathrm{hr}$ at $60^{\circ} \mathrm{C}$. Thick sections $(1 \mu \mathrm{m})$ were cut on a Porter Blum MT-1 ultramicrotome and stained with Paragon (Spurlock et al., 1966) for identification of Leydig cells. From the selected areas, thin silver sections were obtained, placed on uncoated copper grids, stained with uranyl acetate (Watson, 1958) and lead citrate (Reynolds, 1963), and observed without reference to the sources in a Philips EM-300 electron microscope. For light microscopic studies, samples of all testes were obtained after the first hour of

* Postal address: Apartado Postal 73-032, Mexico 73, D.F. 
fixation with Karnovsky's solution and post-fixed by immersion in Zenker's fixative for $24 \mathrm{hr}$. The samples were embedded in paraffin wax, $5 \mu \mathrm{m}$ sections were cut and stained with haematoxylin and eosin. Ten different areas of each testis were selected at random under the light microscope and the Leydig cells appearing within the micrometer grid in the eyepiece were quantitatively evaluated in a blind study.

The total Leydig cell number in the testis on the vasectomized side was compared with that in the contralateral testis and with those in the testes of Group-II and Group-III rats. These specimens were also compared with the Leydig cells of normal young and adult rats previously described (Leeson, 1963).
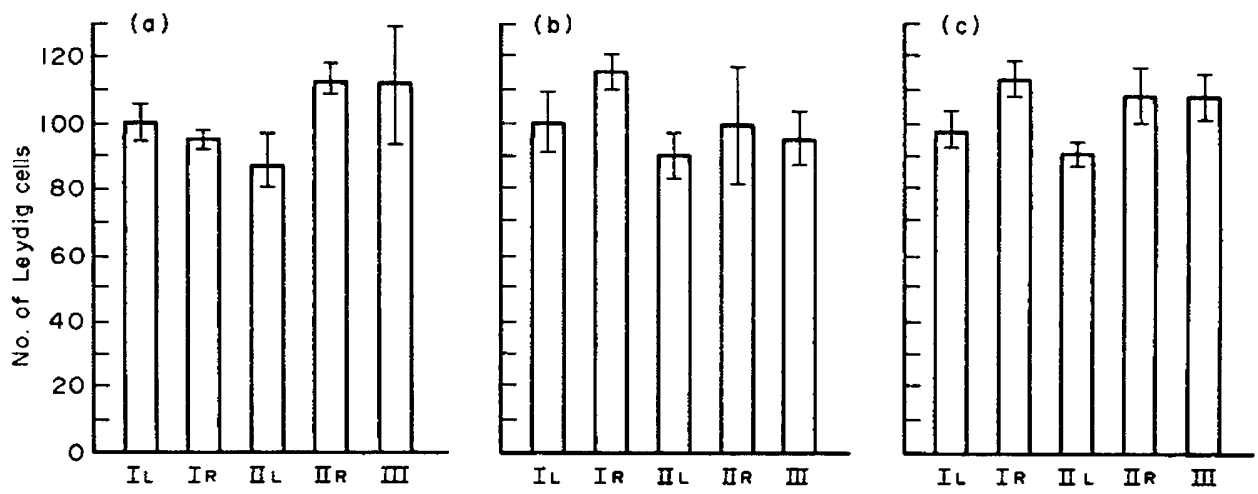

TExT-FIG. 1. Comparisons of the numbers of Leydig cells in the testes of rats (a) 2 months, (b) 4 months, and (c) 6 months after vasectomy. Vertical bars represent the mean \pm S.E., five rats/group. $I_{L}=$ left testes of rats vasectomized on left side; $I_{R}=$ right testes of rats vasectomized on left side; IIL $=$ left testes of sham-operated rats; IIR $=$ right testes of sham-operated rats; III $=$ unoperated control rats. There were no significant differences between the groups by the $\chi^{2}$ test.

There were no significant variations in the weight of testes from the vasectomized side when compared with the contralateral gonads and those from the control animals, and no differences in the numbers of Leydig cells (Text-fig. 1).

Under the light microscope, the Leydig cells appeared histologically normal, and no differences could be found between vasectomized and control groups. The cells were polyhedral with an eosinophilic cytoplasm in which fine granules could be seen. The nuclei were round to oval in shape, and one or two prominent nucleoli were present between dispersed chromatin.

No differences were found between the testes from vasectomized and control rats under the electron microscope. The agranular endoplasmic reticulum occupied most of the cytoplasm. Variation in dilatation and electron density of this cell organelle was observed among the same samples. Lipid storage was not prominent and only a few cells contained lipid droplets. The Golgi complex was usually found in a juxtanuclear position, and consisted of several membranous sacs. Mitochondria were present in great number. They were oval or elongated, with transverse cristae and occasional small dense granules.

Leydig cells are known to be one of the main sources of steroids in testes. The agranular endoplasmic reticulum and microsomes, which are plentiful in 
Leydig cells, have been considered to be the sites of synthesis and metabolism of steroids (Levy et al., 1959; Wattenberg, 1964; Lacy \& Collins, 1973). The microsome fraction of isolated normal and neoplastic Leydig cells converts progesterone to testosterone (Huseby et al., 1961; Christenson \& Mason, 1965). Thus a definite correlation between the ultrastructural morphology of Leydig cells and steroid interaction has been established. Our results clearly demonstrate that there are no significant modifications in Leydig cell number or structure at the times when the testes were studied, and it can be assumed that steroidogenesis in the testes was normal. These results accord with those of Lacy \& Collins (1973) who found a similar steroid metabolism in incubated interstitial tissue from testes of control and vasectomized rats. Nevertheless, long-term studies of testicular morphology and physiology following vasectomy are needed in mammals, including man, in order to determine whether there are changes that are not apparent after only short periods of time.

\section{REFERENCES}

Christensen, A.K. \& Mason, N.R. (1965) Comparative ability of seminiferous tubules and interstitial tissue of rat testes to synthesize androgens from progesterone-4- ${ }^{14} \mathrm{C}$ in vitro. Endocrinology 76, 646-656.

FLICKINGer, C.J. (1972) Ultrastructural study of the rat testis after vasectomy. Anat. Rec. 174, 477-481.

Glauert, A.M. \& Glauert, R.H. (1958) Araldite as an embedding medium for electron microscopy. 7. biophys. biochem. Cytol. 4, 191-194.

Huseby, R.A., Dominguez, O.V. \& Samuels, L.T. (1961) Function of normal and abnormal testicular interstitial cells in the mouse. Recent Prog. Horm. Res. 17, 1-51.

KARNOvsky, M.J. (1965) A formaldehyde-glutaraldehyde fixative of high osmolarity for use in electron microscopy. F. Cell Biol. 17, 137A.

LACY, D. \& Collins, P. (1973) Hormones and contraception in the male and the relative merits of hormonal control and vasectomy. F. Reprod. Fert., Suppl. 18, 185-198.

LeEson, C.R. (1963) Observations on the fine structure of rat interstitial tissue. Acta anat. 52, 34-48.

Levy, H., Deane, H.W. \& RuBin, B.L. (1959) Visualization of steroid-3 $\beta$-ol-dehydrogenase activity in tissues of intact and hypophysectomized rats. Endocrinology 65, 932-943.

Merta, K.C. \& Ramani, P.S. (1970) A simple technique of reanastomosis after vasectomy. Br. F. Urol. $42,340-343$.

MilloNig, G. (1962) Further observations on phosphatase buffer for osmium solution in fixation. Proc. 5th Int. Congr. Electron Microscopy, Vol. 2, p. 8. Ed. S. S. Breese, Jr. Academic Press, New York.

Pardanani, D.S., Kothare, W.L., Mahendrakar, M.N. \& Pradhan, S.A. (1973) The use of a silicone rubber splint for post-vasectomy vas deferens anastomosis. Report of a new operative technique. Contraception 7, 491-501.

Pardanani, D.S., Kothare, W.L., Pradhan, S.A. \& Mahendrakar, M.N. (1974) Surgical restoration of vas continuity after vasectomy: further clinical evaluation of a new operation technique. Fert. Steril. 25, 319-324.

Reynolds, E. (1963) The use of lead citrate at high $\mathrm{pH}$ as an electron opaque stain in electron microscopy. 7. Cell Biol. 17, 208-213.

Spurlock, B.A., Skinner, M.S. \& Kattine, A.A. (1966) A simple rapid method for staining epoxyembedded specimens for light microscopy with the polychromatic stain Paragon-1301. Am. 7 . clin. Path. 46, 252-258.

Watson, M.L. (1958) Staining of tissue sections for electron microscopy with heavy metals. $\mathcal{F}$. biophys. biochem. Cytol. 4, 475-478.

WAtTEnBerg, L.W. (1958) Microscopic histochemical demonstration of steroid-3 $\beta$-ol dehydrogenase in tissue sections. $\mathcal{\mathcal { F }}$. Histochem. Cytochem. 6, 225-236. 